\title{
HERMENÊUTICA E ENSINO JURÍDICO EM TERRAE BRASILIS
}

\section{Lenio Luiz, Streck*}

RESUMO: A discussão acerca do ensino jurídico deve ser feita no contexto das duas grandes revoluções copernicanas que atravessaram o direito e a filosofia no século XX: o constitucionalismo e o ontologische Wendung (giro lingüístico-ontológico). Denuncia-se, assim, que a dogmática jurídica continua refratária a essa ruptura paradigmática, continuando a reproduzir um ensino jurídico estandardizado, que contribui para a ineficácia da Constituição. A hermenêutica filosófica pode ser um importante contributo para a construção de um discurso apto a superar as insuficiências teóricas do senso comum teórico dos juristas.

\section{A N Ã O - R E C E P Ç Ã O D A REVOLUÇÃO COPERNICANA PROPORCIONADA PELO GIRO LINGÜÍSTICO-ONTOLÓGICO}

O século XX mostrou-se generoso para com o direito e a filosofia. Ao menos duas grandes

* Pós-Doutor em Direito; Professor Titular da Unisinos/RS; Professor da Unesa-RJ; Procurador de Justiça/RS; Coordenador do Acordo Internacional CAPES-GRICES (Universidade de Coimbra-Unisinos).
RÉSUMÉ: The discussion concerning the juridical education must be done in the context of the two big Copernicans revolutions that have crossed the law and the philosophy in the twentieth century: the constitutionalism and the ontologische Wendung (ontologicallinguistic turn). One denounces, thus, that the legal dogmatic remains refractory to this paradigmatic disruption, carrying on reproducing a standardized juridical education, which contributes for the ineffectiveness of the Constitution. The philosophical hermeneutic can be an important contribute for the construction of a speech able to overcome the theoretical insufficiencies of the theoretical common sense of jurist.

revoluções alteraram significativamente estes dois ramos do conhecimento científico. Com efeito, no campo jurídico, o direito público assume um lugar cimeiro, a partir da incorporação dos direitos de terceira dimensão ao rol dos direitos individuais (primeira dimensão) e sociais (segunda dimensão). Às facetas ordenadora (Estado Liberal de Direito) e promovedora (Estado Social de Direito), o Estado Democrático de Direito agrega um plus (normativo-qualitativo), 
representado por sua função nitidamente transformadora, uma vez que os textos constitucionais passam a institucionalizar um "ideal de vida boa", a partir do que se pode denominar de co-originariedade entre direito e moral (Habermas).

Os conteúdos compromissórios e dirigentes das constituições - e a do Brasil é típico exemplo - apontam para as possibilidades do resgate das promessas incumpridas da modernidade, questão que assume relevância ímpar em países de modernidade tardia como o Brasil, onde o welfare state não passou de um simulacro. Essa revolução copernicana atravessou o direito público em todos os seus ramos, fazendo com que as relações privadas perdessem a autonomia que haviam adquirido no modelo formal-burguês de direito e de Estado.

No campo filosófico, operou-se uma verdadeira invasão da filosofia pela linguagem, proporcionando uma revolução no modo de compreender o mundo. Superase, assim, o pensamento metafísico que atravessou dois milênios. Afinal, se no paradigma da metafísica clássica os sentidos "estavam" nas coisas e na metafísica moderna, na mente (consciência de si do pensamento pensante), nessa verdadeira guinada pósmetafísica os sentidos passam a se dar na e pela linguagem.

Em outras palavras, é possível dizer que, desde logo, a crise que atravessa a hermenêutica jurídica ${ }^{1}$ possui uma relação direta com a

${ }^{1} \mathrm{O}$ presente texto não prescinde de leituras prévias ou conjuntas, em especial com outras pesquisas que venho desenvolvendo, especialmente constantes em Hermenêutica Jurídica E $(m)$ Crise, 7. ed. Porto Alegre, Livraria do Advogado, 2007 e Verdade e Consenso, 2.ed., Rio de Janeiro, Lumen Juris, 2007. Neles estão desenvolvidos os conceitos aqui trabalhados. discussão acerca da crise do conhecimento e do problema da fundamentação, própria do início do século XX. Veja-se que as várias tentativas de estabelecer regras ou cânones para o processo interpretativo a partir do predomínio da objetividade ou da subjetividade ou, até mesmo, de conjugar a subjetividade do intérprete com a objetividade do texto, não resistiram às teses da viragem lingüístico-ontológica (HeideggerGadamer), superadoras do esquema sujeitoobjeto, compreendidas a partir do caráter ontológico prévio do conceito de sujeito e da desobjetificação provocada pelo circulo hermenêutico e pela diferença ontológica. A viragem hermenêutico-ontológica, provocada por Sein und Zeit (1927) de Martin Heidegger, e a publicação, anos depois, de Wahrheit und Methode (1960), por Hans-Georg Gadamer, foram fundamentais para um novo olhar sobre a hermenêutica jurídica. Assim, a partir dessa ontologische Wendung, iniciase o processo de superação dos paradigmas metafísicos objetivista aristotélico-tomista e subjetivista (filosofia da consciência), os quais, de um modo ou de outro, até hoje têm sustentado as teses exegético-dedutivistassubsuntivas dominantes naquilo que vem sendo denominado de hermenêutica jurídica.

As conseqüências dessa revolucionária viragem lingüístico-ontológica ${ }^{2}$ são

${ }^{2}$ A reviravolta lingüística vai se concretizar como uma nova concepção da constituição do sentido. Esse sentido não pode mais ser pensado como algo que uma consciência produz para si independentemente de um processo de comunicação, mas deve ser compreendido como algo que nós, enquanto participantes de uma práxis real e de comunidades lingüísticas, sempre comunicamos reciprocamente, assinala D. Böhler, citado por Araujo, que acrescenta que essa virada rumo à explicitação de um caráter prático, intersubjetivo e 
incomensuráveis para a interpretação do direito. De terceira coisa que se interpõe entre um sujeito e um objeto, a linguagem passa condição de possibilidade. Para além dos objetivismos e subjetivismos, a hermenêutica filosófica abre um novo espaço para a compreensão do direito e tudo o que representa a revolução copernicana proporcionada pelo novo constitucionalismo. Em outras palavras, essa segunda revolução é condição de possibilidade para o acontecer da primeira. Passamos, pois, do fundamentar (metafísico) para o compreender (fenomenológico).

histórico da linguagem humana tem forte sustentação em Wittgenstein, cuja posição é próxima da nova hermenêutica de matriz heideggeriana. Tanto em Wittgenstein como em Heidegger, a linguagem passa a ser entendida, em primeiro lugar, como ação humana, ou seja, a linguagem é o dado último enquanto é uma ação fática, prática. Precisamente enquanto práxis interativa, ela não pode ser explicada como produto de um sujeito solitário, como ação social, mediação necessária no processo intersubjetivo de compreensão. É justamente aí, diz Araújo, que ocorre a mudança de paradigma: "o horizonte a partir de onde se pode e deve pensar a linguagem não é o do sujeito isolado, ou da consciência do indivíduo, que é o ponto de referência de toda a filosofia moderna da subjetividade, mas a comunidade de sujeitos em interação. A linguagem, enquanto práxis, é sempre uma práxis comum realizada de acordo com regras determinadas. Estas regras não são, contudo, convenções arbitrárias, mas são originadas historicamente a partir do uso das comunidades lingüísticas; são, portanto, costumes que chegam a tornar-se fatos sociais reguladores, ou seja, instituições. Tantas são as formas de vida existentes, tantos são os contextos praxeológicos, tantos são, por conseqüência, os modos de uso de linguagem, numa palavra, os jogos de linguagem. As palavras estão, pois, sempre inseridas numa situação global, que norma seu uso e é precisamente por esta razão que o problema semântico, o problema da significação das palavras, não se resolve sem a pragmática, ou seja, sem a consideração dos diversos contextos de uso. Poder falar significa ser capaz de inserir-se um processo de interação social simbólica de acordo com os diferentes modos de sua realização". Cf. OLIVEIRA, Sobre fundamentação, op. cit., p. 53 e 54. (grifei)
Entretanto, os juristas não se deram conta do fato de que o direito - espaço simbólico das relações de poder - expressase pela linguagem (os fenômenos são levados à representação). Mas a relevante questão está no fato de que, embora direito seja "linguagem", portanto, "texto", este texto é sempre um evento. Não se interpreta em abstrato. Por isso, a tese hermenêutica da applicatio. Por isso, a hermenêutica é faticidade; não é método: é filosofia, é condição de ser no mundo.

No campo jurídico, ocorre uma espécie de fusão/imbricação entre o paradigma (neo)liberal-individualista e o paradigma da filosofia da consciência, que têm um terreno fértil para se concretizarem, mormente em uma sociedade como a brasileira, em que a) o Código Civil é proveniente de uma sociedade pré-liberal e urbana; ${ }^{3}$ b) o Código Penal é produto de uma sociedade que há pouco ingressara no liberalismo, voltado a uma (nova) clientela fruto da mudança da economia ocorrida a partir da revolução liberal de 1930; c) o Código Comercial é do século XIX (agora "alterado", em

${ }^{3}$ Em janeiro de 2003 entrou em vigor o "novo" Código Civil. Uma das características mais marcantes do novo Código - pelo menos, a mais festejada - é a opção pelas cláusulas gerais, constituindo-se como uma espécie de "Código do Juiz". Isso, no entanto, apenas demonstra a prevalência do paradigma da filosofia da consciência (sujeito solipsista - Selbstsüchtiger), no interior do qual o juiz "preenche" as "aberturas hermenêuticas" proporcionadas pelo texto. E isso, como se sabe, é repristinar o velho positivismo, em que os casos "difíceis" são resolvidos por delegação ao juiz que, discricionária e decisionisticamente (Hart e Kelsen), soluciona esses "hard cases". Registro, aqui, para evitar mal-entendidos, que, no paradigma hermenêutico, não se pode distinguir casos simples de casos difíceis. Essa distinção, típica da teoria da argumentação, é metafísica. 
parte, pelo Código Civil); e, d) o Código de Processo Civil, ${ }^{4}$ na mesma linha dos

${ }^{4}$ A discussão em torno da efetividade do processo é de cunho paradigmático. Veja-se que as teses instrumentalistas do processo continuam apostando na "delegação" em favor do juiz da tarefa de "dar agilidade ao processo". Trata-se da afirmação do paradigma da filosofia da consciência, enfim, do solipsismo de um sujeito (juiz) que carrega sobre os ombros a "responsabilidade" de "bem conduzir" o processo. Isso, no fundo, nada mais é do que repristinar a discricionariedade positivista (lembremos do debate Dworkin-Hart).

Em outras palavras, a interpretação (aplicação) do direito fica nitidamente dependente de um sujeito cognoscente, o julgador. Essa dependência do juiz pode ser vista também no campo da assim denominada instrumentalidade do processo. É nessa linha que José Roberto dos Santos Bedaque, prestigiado processualista, procura resolver o problema da efetividade do processo a partir de uma espécie de "delegação" em favor do julgador, com poderes para reduzir as formalidades que impedem a realização do direito material em conflito. E isso é feito a partir de um novo princípio processual decorrente do princípio da instrumentalidade das formas - denominado princípio da adequação ou adaptação do procedimento à correta aplicação da técnica processual. Por este princípio se reconhece "ao julgador a capacidade para, com sensibilidade $e$ bom senso, adequar o mecanismo às especificidades da situação, que não é sempre a mesma" (BEDAQUE, José Roberto dos Santos. Efetividade do Processo e Técnica Processual. São Paulo, Malheiros, 2006, p. 45 grifei). Ou seja, "deve ser o juiz investido de amplos poderes de direção, possibilitando-lhe adaptar a técnica aos escopos do processo em cada caso concreto, mesmo porque a previsão abstrata de todas as hipóteses é praticamente impossivel" (Idem, ibidem, p. 64-65). E como a previsão legislativa não comporta todas hipóteses de aplicação, "observado o devido processo legal, deve ser reconhecido ao juiz o poder de adotar soluções não previstas pelo legislador, adaptando o processo às necessidades verificadas na situação concreta" (idem, ibidem, p. 571). Em sua - refira-se sofisticada tese, embora demonstre preocupação em afastá-la da discricionariedade, Bedaque termina por sufragar (ainda que implicitamente) as teses hartianas e kelsenianas, quando admite que as fórmulas legislativas abertas favorecem essa atuação judicial: "Quanto mais o legislador valer-se de formas abertas, sem conteúdo jurídico definido, maior será a possibilidade de o juiz adaptá-la às necessidades do caso concreto. Esse poder demais Códigos, estabelece mecanismos que protegem explicitamente os direitos reais em detrimento dos direitos pessoais. A (dupla) crise se instala, pois, na emergência de novos conflitos e novos mecanismos de resolução de conflitos e no papel que o direito assume no interior de um novo modelo de Estado.

Tudo isto passa a ter influência e importância na análise do direito em nosso país. Como os juristas pensam o mundo e o direito? Como se inserem e como têm acesso ao mundo? Com efeito, do Estado Liberal já passamos - formalmente - por um Estado Social (não realizado) e, a partir de 1988, passamos a ter uma Constituição que instituiu o Estado Democrático de Direito. Este é o cerne de uma crise do modelo liberal-individualista-normativista, fundado no paradigma solipsista. ${ }^{5}$ Ideologicamente, essa (dupla) crise de paradigma se sustenta em um emaranhado de crenças, fetiches, valores e justificativas por meio de disciplinas específicas, denominado por Warat de sentido comum teórico dos juristas. ${ }^{6}$

O sentido comum teórico sufoca as possibilidades interpretativas. Quando submetido à pressão do novo, (re)age

não se confunde com a 'discricionariedade judicial', mas implica ampliação da margem de controle da técnica processual pelo legislador" (idem, ibidem, p. 109). Veja-se, portanto, que o problema possui um fundo paradigmático. Continua-se a apostar no sujeito solipsista. Assim tem ocorrido com as diversas reformas e mini-reformas no processo civil no decorrer dos últimos anos.

${ }^{5} \mathrm{O}$ texto preocupa-se em abordar a assim denominada crise do paradigma liberal-individualista de produção de direito, agregada à crise do Estado e à crise decorrente da não-superação, pela dogmática jurídica, do paradigma da prevalência da lógica do sujeito cognoscente.

${ }^{6}$ WARAT, Luis Alberto. Introdução geral ao direito I. Porto Alegre, Fabris, 1994, p. 57. 
institucionalizando a crítica. Para tanto, abre possibilidades de dissidências apenas possíveis (delimitadas previamente). $\mathrm{Ou}$ seja, no interior do sentido comum teórico, permite-se, difusamente, (apenas) o debate periférico, mediante a elaboração de respostas que não ultrapassem o teto hermenêutico prefixado (horizonte do sentido).

Daí a dificuldade para a obtenção de algumas respostas que exsurgem de perguntas do tipo "o que significa o dispositivo constitucional da igualdade de todos perante a lei" para a imensa maioria da população brasileira? O que significa pacta sunt servanda em um conflito sociojurídico entre incluídos e excluídos (socialmente)?

O jurista tradicional, inserido em uma tradição jurídico-social inautêntica (vejase a proximidade, neste ponto, da noção de tradição inautêntica com o conceito de senso comum teórico), não se dá conta dessa problemática. Observe-se, por exemplo, que não é gratuita a colocação do crime de estupro no capítulo dos crimes contra os costumes, em vez de inseri-lo no capítulo dos crimes contra a vida ou contra a integridade corporal! Por isso não pode surpreender o fato de que o Código Penal "protege-pune" com mais rigor os crimes contra a propriedade do que os contra a vida. As comparações chegam a ser teratológicas, por exemplo, entre lesões culposas (crimes de trânsito) e furto, estelionato e omissão de socorro, sem falar na comparação entre o tratamento conferido aos crimes de sonegação de tributos e ao furto...

Inserido em um habitus dogmaticus, o jurista não se dá conta das contradições do sistema jurídico. Estas não "aparecem" aos olhos do jurista, uma vez que há um processo de justificação/fundamentação da "coerência" do seu próprio discurso. Por isso, esse processo de justificação não prescinde, para sua elucidação, do entendimento acerca do funcionamento da ideologia. Em outras palavras, ainda é necessário estudar o (velho) conceito de ideologia, que parece ter sido esquecido nas salas de aula das tantas faculdades de direito existentes pelo país afora. Talvez porque, como ensina Zizek, a eficácia de uma ideologia é apreendida pelos mecanismos da identificação imaginária e da identificação simbólica. E, à primeira vista se poderia dizer que o que é pertinente numa análise da ideologia é somente a maneira pela qual ela funciona como discurso, em suma, pela maneira como os mecanismos discursivos constituem o campo da significação ideológica. No entanto, o derradeiro suporte do efeito ideológico (ou seja, a maneira como uma rede ideológica nos "prende”) é o núcleo fora de sentido, pré-ideológico do gozo. Na ideologia "nem tudo é ideologia (isto é, sentido ideológico)", mas é precisamente esse excesso que constitui o derradeiro esteio da ideologia".?

O ideológico não pode ser simbolizado enquanto ideológico, ou seja, usando as palavras de Sizek, o indivíduo submetido à ideologia nunca pode dizer por si mesmo “estou na ideologia”. Esse não-poderdizer é decorrente do fato de que o discurso do "outro" o aliena dessa possibilidade simbolizante. É possível dizer, assim, que o discurso ideológico enquanto tal não é realidade para o indivíduo submetido/ assujeitado. Se simbolizar é tratar pela

${ }^{7}$ Cf. ZIZEK, Slavoj. Eles não sabem o que fazem. O sublime objeto da ideologia. Rio de Janeiro: Zahar, 1992. p. 122. 
linguagem, e se o inconsciente é estruturado como uma linguagem, o discurso ideológico só pode vir à tona no sujeito se este não tiver as condições de possibilidade de dizê-lo, de nomeá-lo, isto é, de estabelecer a surgição de que fala Lacan no Seminário II. Nesse sentido, é possível fazer uma analogia do discurso ideológico com o discurso do mito. A ideologia - vista/entendida segundo os parâmetros aqui estabelecidos - permite que se diga que o mito só é mito para quem não sabe que é mito, ou seja, o mito só é mito para quem nele acredita. $O$ desvelar do mito é a instituição de uma ruptura, através de um simbólico não atravessado/sitiado pelo discurso mitológico.

No plano dessa justificação discursiva, objetivando a perenização desse corpus ideologicus, a dogmática jurídica utiliza-se de um artifício que Ferraz Jr. denomina de astúcia da razão dogmática, que atua mediante mecanismos de deslocamentos ideológico-discursivos. ${ }^{8}$ Ou seja, a partir desse deslocamento, não se discute, por exemplo, o problema dos direitos humanos e da cidadania, mas sim, sobre (e a partir) deles.

Graças a isso, no contexto da dogmática jurídica, os fenômenos sociais que chegam ao Judiciário passam a ser analisados como meras abstrações jurídicas, e as pessoas, protagonistas do processo, são transformadas em autor e réu, reclamante e reclamado, e, não raras vezes, "suplicante" e "suplicado", expressões estas que, convenhamos, deveriam envergonhar (sobremodo) a todos nós. Mutatis mutandis, isto significa dizer que os conflitos sociais não entram nos fóruns e nos tribunais

${ }^{8}$ Consultar FERRAZ Jr, Tércio Sampaio. Introdução ao estudo do direito. São Paulo: Atlas, 1987. p. 280. graças às barreiras criadas pelo discurso (censor) produzido pela dogmática jurídica dominante. Nesse sentido, pode-se dizer que ocorre uma espécie de "coisificação" (objetificação) das relações jurídicas.

Embora esse processo ocorra cotidiana e difusamente no interior dessa tradição inautêntica que forja os pré-juízos inautênticos (falsos) dos juristas, alguns exemplos mais contundentes põem à prova até mesmo a relação "sentido comum teórico dos juristas" versus "senso comum da sociedade". Assim, v.g, graças ao modo de fazer/interpretar o direito balizado pelo sentido comum teórico e pelo habitus por ele instituído, é (foi) "permitido" que, no âmbito do direito penal, em face de um conflito de dispositivos legais (Lei $8.069 v$. Lei 8.072), defender a tese de que quem estupra uma criança pode ter uma pena mais branda do que aquele que estupra uma mulher adulta (existiram posições doutrinárias e até mesmo julgamentos nesse sentido, sim!). Na verdade, nesse caso, em vez de discutirem a lei, os juristas discutiram sobre a e a partir da lei, como se esta (a lei) fosse fruto de um legislador racional. Sobre a Constituição, ninguém falou. Esse deslocamento discursivo, de cunho ideológico, é próprio do sentido comum teórico dos juristas, que produz os standards a serem utilizados pela comunidade jurídica. Resulta disso uma interpretação totalmente alienada/afastada das relações sociais, ou seja, pouco importa ao jurista, inserido na tradição inautêntica do direito, o conteúdo das relações sociais. Pouco importa a teratologia resultante do paradoxo que é a imposição de uma pena mais branda a quem estupra uma criança em comparação com aquele que estupra uma mulher adulta... 
Não se pensou em aprofundar a matéria, a partir de um olhar em outra tradição jurídica, como, por exemplo, o direito alemão, a partir dos princípios da proibição de excesso (Übermassverbot) e da proibição de proteção insuficiente (Untermassverbot). ${ }^{9} \mathrm{O}$ que parece que importa mesmo é fazer uma "boa hermenêutica"; o importante é "resolver, com competência dogmática, 'neutralmente', as antinomias" do sistema... E as antinomias obscurecem (escondem) o exame da parametricidade constitucional (veja-se o problema recorrente no direito: ainda não conseguimos elaborar uma adequada teoria das fontes). Enfim, tamanha foi a dimensão da crise, que o establishment jurídico-dogmático não conseguiu "resolver o problema" no plano da hermenêutica. Ou seja, tão forte é o corpus introduzido pelo sentido comum teórico, que, na impossibilidade de ver resolvido o "problema hermenêutico", o "sistema" teve que recorrer ao "legislador racional" que, mediante a edição da lei federal n. 9.291, de 4 de junho de 1996, revogou os parágrafos únicos em questão.

No mesmo rumo, preso às amarras dessa tradição inautêntica, um juiz de direito concedeu liminar de reintegração de posse em favor de fazendeiro que ocupava terras de propriedade do governo, para desalojar centenas de sem-terras, sem examinar se eram ou não particulares. Resultado disso é que morreram várias pessoas... Para o

9 Sobre a Übermassverbot e a Untermassverbot, ver meu artigo Bem jurídico e Constituição: da Proibição de Excesso (Übermassverbot) à Proibição de Proteção Deficiente (Untermannverbot): de como não há blindagem contra normas penais inconstitucionais. Boletim da Faculdade de Direito de Coimbra, v.80, ano 2004, pp. 303-345. magistrado, não se tratava de um conflito social, mas apenas de um problema decidível no âmbito da juridicidade. Veja-se como foi esquecida a revolução copernicana do direito público; a decisão mostra nitidamente a prevalência do positivismo, que objetiva exorcisar o mundo do direito dos fatos que "o atrapalham". Talvez o problema, em um país como o Brasil, seja, efetivamente, o excesso de realidade...!

Os exemplos são intermináveis, sendo mais importantes por seu aspecto simbólico do que pela sua significação "real". Como bem diz Cornelius Castoriadis, o gesto do carrasco é real por excelência, mas é imediatamente também simbólico em outro nível. Ou seja, um sistema de direito, que se constrói a partir de doutrina, jurisprudência, legislação, etc, existe socialmente enquanto sistema simbólico. As coisas não se esgotam no simbólico (os atos reais, individuais ou coletivos, o trabalho, o consumo, a guerra, o amor, a natalidade, não são, nem sempre, nem diretamente, símbolos); mas elas só podem existir no simbólico e são impossíveis fora de um simbólico. E o estado da arte da operacionalidade do direito se agrava, agora, com a institucionalização das súmulas vinculantes, mecanismo que representa um visível retrocesso hermenêutico, porque promove um retorno do direito à metafísica clássica. Com as súmulas, parece que o senso comum teórico atinge o seu apogeu: uma volta ao mundo das regras e às "facilidades objetivistas" oferecidas pela metodologia subsuntiva-dedutiva. Ou seja, quando o sistema se encontra em face de incertezas significativas ("casos difíceis" e tudo o que isso representa), basta elaborar uma súmula "apta" a resolver os "casos futuros". 
Retorna-se, de forma sofisticada, ao modelo formal-burguês, isto é, na medida em que as súmulas antecipam o discurso de validade, a tarefa dos aplicadores estará restrita ao "encaixe" da situação fática (subsunção), com uma agravante: na medida em que súmulas são textos e na medida em que o positivismo interpreta textos sem coisas, também as súmulas serão vitimadas pelo positivismo. Não esqueçamos novamente o problema presente na-aparente-contradição existente em Dworkin ao propor a sua tese da one right answer em um sistema de direito avançado, isto, com forte e consistente mecanismo de vinculação jurisprudencial como é o norteamericano. É que até mesmo o sistema de precedentes necessita de "blindagens" contra discricionariedades interpretativas...! Para tanto, basta ver a aplicação da "fórmula" de aplicação de precedentes proposta pelo Justice Scalia. ${ }^{10}$

Destarte, de um lado ter-se-á - como de há muito vem ocorrendo - aplicações das súmulas no atacado, com o sacrifício dos casos concretos, os quais, lembremos da metáfora do Leito de Procusto, serão confinados a um espaço de sentido previamente delimitado (afinal, a súmula é uma resposta a priori); de outro, no varejo, apreciações de cunho meramente analítico-conceitual procurarão construir os desvios ou atalhos interpretativos necessários para a manutenção do sentido

${ }^{10}$ Para tanto, ver TRIBE, Laurence e DORF, Michael. On reading the Constitution. President and Fellows of Harward College, 2005, assim como a apresentação que fiz à edição brasileira ("Interpretando a Constituição: Sísifo e a tarefa do hermeneuta. Um manifesto de Laurence Tribe e Michael Dorf em favor da proteção substantiva dos direitos fundamentais". In: Hermenêutica Constitucional. Belo Horizonte, Del Rey, 2007). comum teórico. De todo modo, como sempre tem ocorrido, o positivismo discricionário, darwinianamente, saberá se adaptar às novas/velhas circunstâncias, contornando o problema sem precisar abandonar a tese central que o sustenta: o máximo de subjetivismo para preservar as suas "reservas de sentido", que serão utilizadas sempre que for necessário impor a wille zur Macht. Em outras palavras, na medida em que se constituem em um projeto de poder, as súmulas serão "obedecidas" enquanto estiverem em conformidade com esse projeto; aquelas que forem "desviantes" terão seus próprios "limites semânticos" ultrapassados. E tudo começará novamente...!

\section{DOGMÁTICA E ENSINO JURÍDICO: O DITO E O NÃO-DITO - O UNIVERSO DO SILÊNCIO (ELOQÜENTE) DO IMAGINÁRIO DOS JURISTAS}

Em face do que foi analisado anteriormente, uma pergunta se torna inevitável: que tipo de visão têm os operadores jurídicos, mergulhados nessa "inautenticidade" (no sentido hermenêutico da palavra), acerca da aplicação do direito? Evidentemente, os exemplos antes delineados apontam apenas em direção à ponta do iceberg. É também evidente que a (con)formação desse sentido comum teórico tem uma relação direta com o processo de aprendizagem nas escolas de direito. Com efeito, o ensino jurídico continua preso às velhas práticas. Por mais que a pesquisa jurídica tenha evoluído a partir do crescimento do número de programas de pós-graduação, estes influxos reflexivos ainda estão distantes das salas de aula 
dos cursos de graduação, não se podendo olvidar, nesse contexto, que o crescimento da pós-graduação é infinitamente inferior à explosão do número de faculdades instaladas nos últimos anos.

A cultura calcada em manuais, muitos de duvidosa cientificidade, ainda predomina na maioria das faculdades de direito. ${ }^{11}$ Forma-se, assim, um imaginário que "simplifica" o ensino jurídico, a partir da construção de standards e lugares comuns, repetidos nas salas de aula e, posteriormente, nos cursos de preparação para concursos (hoje já existem cursinhos de preparação para ingresso nos cursinhos), bem como nos fóruns e tribunais. Essa cultura alicerça-se em casuísmos didáticos. O positivismo ${ }^{12}$ ainda é a regra, calcado, de um lado, em um objetivismo que não diferencia texto e norma e, de outro, em um subjetivismo que ignora os limites semânticos do texto jurídico (portanto, desconfie-se tanto do professor que diz que a lei contém um sentido em si mesmo como daquele que, pensando ser crítico, diz para os alunos: "a lei não importa muito, pois ela é apenas a ponta do iceberg..." - os dois são positivistas). A dogmática jurídica trabalhada nas salas de aula (e reproduzida

${ }^{11}$ Pela "simploriedade" e nível de estandardização de alguns livros jurídicos, deveria ser colocada uma tarja como aquelas que se põem nos maços de cigarro: "o uso constante deste material fará mal a sua saúde mental"...!

${ }^{12} \mathrm{O}$ positivismo é entendido, aqui, principalmente a partir daquilo que considero a sua principal caracterísitica e que deu azo às críticas de Dworkin à Hart: a discricionariedade, que é antidemocrática. Por isso é que, à luz da hermenêutica filosófica - retrabalhada por mim como uma Nova Crítica do Direito -, proponho não somente a possibilidade de construirmos respostas corretas em direito, mas também a necessidade de atingirmos tal desiderato. em boa parte dos manuais) considera o direito como sendo uma mera racionalidade instrumental. Em termos metodológicos, predomina o dedutivismo (sic), a partir da reprodução inconsciente da metafísica relação sujeito-objeto (registre-se: tanto a metafísica clássica como a metafísica moderna). ${ }^{13}$ Nesse contexto, o próprio ensino jurídico é encarado como uma terceira coisa, no interior da qual o professor é um outsider do sistema.

A doutrina que sustenta o saber jurídico resume-se a um conjunto de comentários resumidos de ementários de jurisprudência, desacompanhados dos respectivos contextos. Cada vez mais, a doutrina doutrina menos, ${ }^{14}$

${ }^{13}$ Nesta quadra do tempo, não é mais possível defender o método dedutivo, a subsunção etc. Pensar assim é fazer uma profissão de fé no esquema sujeitoobjeto. Remeto o leitor, mais uma vez, ao meu Hermenêutica Jurídica E(m) Crise.

${ }^{14}$ Despiciendo lembrar que as críticas aqui lançadas dizem respeito à dogmática jurídica tradicional, ainda refém de um senso comum teórico positivistanormativista. Em contrapartida, a esse "saber congelado", há no Brasil frutífera produção doutrinária que aponta para um Direito de feição transformadora, perfeitamente engajada na construção de um Estado Democrático (e Social) de Direito. Dito de outro modo, a crítica à dogmática jurídica não significa, a toda evidência, qualquer pregação no sentido de que a dogmática jurídica seja despicienda. A dogmática jurídica pode ser crítica. E deve ser crítica. Afinal, não há direito sem dogmática, como bem assevera Jacinto Coutinho. É exatamente a partir de uma dogmática jurídica consistente e crítica que se pode construir as condições para evitar - ou minimizar - os decisionismos e as discricionariedades. Na arguta observação de Jacinto Coutinho, "não há direito sem uma dogmática onde as palavras tenham um sentido aceito pela maioria, ainda que elas escorreguem e, de tanto em tanto, mereçam - e tenham uma alteração de curso. Metáforas e metonímias (ou condensações e deslocamentos, como queria Freud), a partir da demonstração de Lacan, esvaziam de sentido (ou conteúdo) preestabelecido qualquer palavra que ganhe um giro marcado pela força pulsional e, portanto, determinada pelo inconsciente. Falar de dogmática enquanto descrição das regras jurídicas em vigor (Haesaert) -, contudo, não é falar de dogmatismo; 
isto é, a doutrina não mais doutrina ${ }^{15}$ - é,

e isto é despiciendo discutir. Sem embargo, não são poucos os que confundem - e seguem confundindo - os dois conceitos, com efeitos desastrosos para o direito. Quando se fala de dogmática e o interlocutor pensa em dogmatismo, a primeira reação, invariavelmente, é de desprezo; e por que não de medo, mormente se se quer algo que possa suportar uma postura avançada, de rompimento com o status quo. Sem embargo do erro grosseiro, a situação cria embaraços e constrangimentos, exigindo uma faina dissuasiva elaborada e complexa, com efeitos duvidosos porque se não tem presente os reais resultados.(...) A dogmática, então, precisa ser crítica (do grego kritiké, na mesma linha de kritérion e krisis) para não se aceitar a regra, transformada em objeto, como uma realidade. Isso só é possível, por evidente, porque se tem presente que o real é impossível quando em jogo a sua apreensão e, com muito custo, que a parcialidade a que se chega depende, no seu grau (embora difícil mensurar o quantum), de muitos saberes que não aquele jurídico. Trata-se, portanto, de uma linha média, que não abdica, de forma alguma, da dogmática (dado ser imprescindível o seu conhecimento, sob pena de se não ter juristas, mas verdadeiros gigolôs), a qual deve estar sempre atenta ás arapucas ideológicas do positivismo e, assim, abre-se, por necessidade, por ser imperioso, a outros saberes, a serem dominados na medida do possível". Cf. Coutinho, Jacinto Nelson de Miranda. Dogmática crítica e limites lingüísticos da lei. Revista do Instituto de Hermenêutica Jurídica-Crítica à dogmática: dos bancos acadêmicos

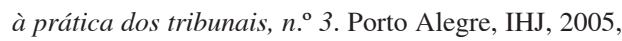
pp. 37 e segs.

${ }^{15}$ Para ilustrar a dimensão dessa problemática, vejase contemporânea decisão do Superior Tribunal de Justiça, na qual o Ministro Humberto Gomes de Barros, no AgRg em EREsp n. ${ }^{\circ}$ 279.889-AL, assim se pronunciou: "Não me importa o que pensam os doutrinadores. Enquanto for Ministro do Superior Tribunal de Justiça, assumo a autoridade da minha jurisdição. O pensamento daqueles que não são Ministros deste Tribunal importa como orientação. A eles, porém, não me submeto. Interessa conhecer a doutrina de Barbosa Moreira ou Athos Carneiro. Decido, porém, conforme minha consciência. Precisamos estabelecer nossa autonomia intelectual, para que este Tribunal seja respeitado. É preciso consolidar o entendimento de que os Srs. Ministros Francisco Peçanha Martins e Humberto Gomes de Barros decidem assim, porque pensam assim. E o STJ decide assim, porque a maioria de seus integrantes pensa como esses Ministros. Esse é o pensamento do Superior Tribunal de Justiça, e a doutrina que se amolde a ele. É fundamental expressarmos o que somos. Ninguém nos dá lições. Não somos aprendizes de ninguém. Quando viemos para sim, doutrinada pelos tribunais. É nisto que se baseia o casuísmo didático: a partir da construção de "categorias", produzemse raciocínios "dedutivos", como se a realidade pudesse ser aprisionada no "paraíso dos conceitos do pragmatismo positivista dominante”.

Não é desarrazoado afirmar, destarte, que a hermenêutica praticada nas salas de aula continua absolutamente refratária ao giro lingüístico-ontológico (ontologische Wendung); em regra, continua-se a estudar os métodos tradicionais de interpretação (gramatical, teleológico etc.), como se o processo de interpretação pudesse ser feito em partes ou em fatias. A teoria do Estado, condição de possibilidade para o estudo do Direito Constitucional (para ficar nesta disciplina fundamental, que, aliás, não ocupa, na maioria dos cursos jurídicos, mais do que dois semestres), não vem acompanhada da necessária interdisciplinariedade.

este Tribunal, corajosamente assumimos a declaração de que temos notável saber jurídico - uma imposição da Constituição Federal. Pode não ser verdade. Em relação a mim, certamente, não é, mas, para efeitos constitucionais, minha investidura obriga-me a pensar que assim seja" (grifos meus). Guardado o contexto no qual foi proferida, a assertiva do magistrado não pode ficar isenta de uma crítica à luz dos pressupostos filosóficos que sustentam as contemporâneas teorias do direito. De efetivo, é preciso dizer, de pronto, que o direito não é aquilo que os Tribunais dizem que é, como se estívessemos a sufragar a velha tese do realismo norte-americano. Só que não é bem assim, ou, melhor dizendo, não pode ser assim. Com efeito, o direito é algo bem mais complexo do que o produto da consciênciade-si-do-pensamento-pensante (Selbstgewissheit des denkenden Denken), que caracteriza a (ultrapassada) filosofia da consciência, como se o sujeito assujeitasse o objeto. $\mathrm{O}$ ato interpretativo não é produto nem da objetividade plenipotenciária do texto e tampouco de uma atitude solipsista do intérprete: o paradigma do Estado Democrático de Direito está assentado na intersubjetividade. 
Em síntese: é preciso compreender que a crise do ensino jurídico é, antes de tudo, uma crise do direito, que na realidade é uma crise de paradigmas, assentada em uma dupla face: uma crise de modelo e uma crise de caráter epistemológico. De um lado, os operadores do direito continuam reféns de uma crise emanada da tradição liberalindividualista-normativista (e iluminista, em alguns aspectos); e, de outro, a crise dos paradigmas epistemológico da filosofia da consciência - metafísica moderna - e aristotélico-tomista, da metafísica clássica). O resultado dessa(s) crise(s) é um direito alienado da sociedade, questão que assume foros de dramaticidade se compararmos o texto da Constituição com as promessas da modernidade incumpridas.

Os próprios exemplos utilizados em sala de aula ou em determinadas obras jurídicas estão descontectados do que acontece no cotidiano da sociedade. Isto decorre de uma cultura estandardizada, no interior da qual a dogmática jurídica trabalha com prêt-àporters significativos. Há uma proliferação de manuais, que procuram "explicar" o direito a partir de verbetes jurisprudenciais ahistóricos e atemporais (portanto, metafísicos).

Ocorre, assim, uma ficcionalização do mundo jurídico, como se a realidade social pudesse ser procustianamente aprisionada/ moldada/explicada através de verbetes e exemplos com pretensões universalizantes (lembremos das súmulas vinculantes, agora instituciozalizadas pela EC 45/04). Não é necessário repisar os inúmeros exemplos parte dos quais beiram ao folclórico - que povoam os livros jurídicos utilizados nas salas de aulas (e nos fóruns e tribunais). Veja-se o caso da explicação do "estado de necessidade" constante no art. 24 do Código Penal, não sendo incomum encontrar professores (ainda hoje) usando o exemplo do naufrágio em alto-mar, em que duas pessoas (Caio e Tício, personagens comuns na cultura dos manuais) "sobem em uma tábua”, e na disputa por ela, um deles é morto (em estado de necessidade, uma vez que a tábua suportava apenas o peso de um deles...!). ${ }^{16}$ Cabe, pois, a pergunta: por que o professor (ou o manual), para explicar a excludente do estado de necessidade, não usa um exemplo do tipo "menino pobre entra no Supermercado Carrefour e subtrai um pacote de bolacha a mando de sua mãe, que não tem o que comer em casa?" Mas isto seria exigir demais da dogmática tradicional. Afinal de contas, exemplos deste tipo aproximariam perigosamente a ciência jurídica da realidade social...!

Tudo isto serve para demonstrar/ilustrar a histórica dificuldade da dogmática jurídica em lidar com os fenômenos sociais. Vários fatores tiveram e têm influência nessa problemática. Como muito bem diz Ferraz Jr., "é preciso reconhecer que, nos dias

\footnotetext{
${ }^{16} \mathrm{Na}$ mesma linha, em importante concurso público realizado no Rio Grande do Sul, perguntou-se: Caio quer matar Tício, com veneno; ao mesmo tempo, Mévio também deseja matar Tício (igualmente com veneno!). Um não sabe da intenção assassina do outro. Ambos ministram apenas a metade da dose letal (na pergunta, não há qualquer esclarecimento acerca de como o personagem Tício - com certeza, um idiota -, bebe as duas porções de veneno). Em conseqüência da ingestão das meia-doses, Mévio vem a perecer... Encerrando, a questão do aludido concurso indagava: Caio e Mévio respondem por qual tipo penal??? Em outro concurso, de âmbito nacional, a pergunta dizia respeito à solução jurídica a ser dada ao caso de um gêmeo xifópago ferir o outro (com certeza, gêmeos xifópagos andam armados e, em cada esquina, encontramos vários deles...!).
} 
atuais, quando se fala em Ciência do Direito, no sentido do estudo que se processa nas Faculdades de Direito, há uma tendência em identificá-la com um tipo de produção técnica, destinada apenas a atender às necessidades do profissional (o juiz, o promotor, o advogado) no desempenho imediato de suas funções. Na verdade, nos últimos cem anos, o jurista teórico, pela sua formação universitária, foi sendo conduzido a esse tipo de especialização, fechada e formalista" ${ }^{17}$ Escrita há tantos, a advertência/denúncia de Ferraz Jr. ainda continua atual.

Em outras palavras, estabeleceu-se uma cultura jurídica standard, no interior da qual o operador do direito vai trabalhar, no seu cotidiano, com soluções e conceitos lexicográficos, recheando, desse modo, suas petições, pareceres e sentenças com ementas jurisprudenciais, citadas, quase sempre, de forma descontextualizada, afora sua atemporalidade e ahistoricidade. Para tanto, os manuais jurídicos põem à disposição dos operadores uma coletânea de prêts-à-porter significativos, representados por citações de resumos de ementas e verbetes doutrinários (extraídos, na sua maioria, de acórdãos), normalmente uma a favor e outra contra determinada tese.

Com um pouco de atenção e acuidade, pode-se perceber que grande parte de sentenças, pareceres, petições e acórdãos é resolvida a partir de citações do tipo: "Nessa linha, a jurisprudência é pacífica" (e seguem-se várias citações padronizadas de número de ementários); ou: “Já decidiu o Tribunal tal que legítima defesa não se mede

${ }^{17}$ Cf. FERRAZ Jr., Introdução ao estudo do direito, op. cit., p. 49. milimetricamente” (RT 604/327) (sic); ainda, que "abraço configura o crime de atentado violento ao pudor, cuja pena - ressalte-se, varia de seis a dez anos de reclusão, além de ser crime hediondo" (RT 567/293; RJTJSP 81/351) (sic). São citados, geralmente, tão-somente os ementários, produtos, em expressivo número, de outros ementários (ou da fusão destes). Raramente a ementa citada vem acompanhada do contexto históricotemporal que cercou o processo originário.

Consequiência disso é que o processo de interpretação da lei passa a ser um jogo de cartas (re)marcadas (Ferraz Jr., Bairros de Brum, J. E. Faria e Warat). Ainda se acredita na ficção da vontade do legislador, do espírito do legislador, da vontade da norma (sic)..$^{18}$ É relevante frisar, destarte, que toda esta problemática se forja no interior do que se pode chamar de establishment jurídico, que atua de forma difusa, buscando uma espécie de "uniformização de sentido", que, segundo Bourdieu e Passeron, ${ }^{19}$ tem uma relação direta com um fator normativo de poder, $o$ poder de violência simbólica. E é inegável o poder de violência simbólica que tem o ensino jurídico.

Apesar de tudo isso, o Direito, instrumentalizado pelo discurso dogmático, consegue (ainda) aparecer, aos olhos do usuário/operador do Direito, como, ao mesmo tempo, seguro, justo, abrangente, sem fissuras, e, acima de tudo, técnico e funcional. Em contrapartida, o preço que se

\footnotetext{
${ }^{18}$ Ver meu Hermenêutica Jurídica E(m) Crise.

${ }^{19}$ Cf. BOURDIEU, Pierre e PASSERON, Jean Claude. A reprodução: elementos para uma teoria do sistema de ensino. São Paulo: Ed. Francisco Alves,
} 1975. p. 19-24. 
paga é alto, uma vez que ingressamos, assim, "num universo de silêncio: um universo do texto, do texto que sabe tudo, que diz tudo, que faz as perguntas e dá as respostas. Nestes termos, conclui Legendre, os juristas fazem um trabalho doutoral no sentido escolástico da palavra. Em outras palavras, fazendo seu trabalho, eles não fazem o Direito; apenas entretêm o mistério divino do Direito, ou seja, o princípio de uma autoridade eterna fora do tempo e mistificante, conforme as exigências dos mecanismos de controle burocrático num contexto centralista". ${ }^{20}$

\section{A FETICHIZAÇÃO DO DISCURSO E O DISCURSO DA FETICHIZAÇÃO:}

A DOGMÁtica JURÍdicA, O DISCURSO JURÍdICO E A INTERPRETAÇÃO DA LEI AINDA A “ESTANDARDIZAÇÃO DO DIREITO"

À evidência, o Judiciário e as demais instâncias de administração da justiça são atingidos diretamente por essa crise. Com efeito, o sistema de administração da justiça (Magistratura, Ministério Público, Advocacia de Estado, Defensoria Pública e Polícia) consegue enfrentar, de forma mais ou menos eficiente, os problemas que se apresentam rotinizados, sob a forma de problemas estandardizados. Quando, porém, surgem questões macrossociais, transindividuais, e que envolvem, por exemplo, a interpretação das ditas "normas programáticas" constitucionais, tais instâncias, mormente o Judiciário, procuram, nas brumas do sentido

${ }^{20}$ Cf. FERRAZ Jr., Função Social da Dogmática Jurídica. São Paulo: Revista dos Tribunais, 1980. p. 178. comum teórico dos juristas, interpretações despistadoras, tornando inócuo/ineficaz o texto constitucional. Isto porque o "discursotipo" (Veron) da dogmática jurídica estabelece os limites do sentido e o sentido dos limites do processo hermenêutico. Conseqüentemente, estabelece-se um enorme hiato que separa os problemas sociais do conteúdo dos textos jurídicos que definem/asseguram os direitos individuais e sociais.

Por isso, insisto na importância da relação entre o modo-de-fazer-Direito e a concepção de Estado vigente/dominante. Isto porque a inefetividade de inúmeros dispositivos constitucionais e a constante redefinição das conquistas sociais através de interpretações despistadoras/redefinitórias feitas pelos Tribunais brasileiros têm uma direta relação com o modelo de hermenêutica jurídica que informa a atividade interpretativa da comunidade jurídica.

Esse hiato (hermenêutico) entre a concepção de direito vigorante no modelo de Estado Liberal e no Estado democrático de Direito e a (conseqüente) crise de paradigma de dupla face (crise do paradigma liberalindividualista-normativista e crise dos paradigmas epistemológico-subjetivista da filosofia da consciência e objetivistaaristotélico-tomista), retratam a incapacidade histórica da dogmática jurídica em lidar com os problemas decorrentes de uma sociedade díspar/excludente como a brasileira. ${ }^{21}$

\footnotetext{
${ }^{21}$ Pesquisa de Sérgio Adorno acerca da história do ensino jurídico no Brasil dá conta de que, já no seu nascedouro, o "segredo" do ensino jurídico decorre da síntese entre patrimonialismo e liberalismo. Destarte, desde o início o Brasil privilegiou a autonomia da ação individual em lugar da ação coletiva; conferiu primazia ao princípio da liberdade em lugar do princípio da
} 
Do que foi dito, penso que, sem modificar o nosso modo de compreender o mundo, sem superar o esquema sujeito-objeto, sem superar a cultura manualesca que assola e domina o imaginário dos juristas, sem superar a discricionariedade positivista e a falsa impressão de que são críticas determinadas posturas subjetivistas-axiologistas que desconsideram o texto (inclusive da Constituição), parece temerário falar no resgate do papel transformador do direito, entendido como aquele que exsurge do papel dirigente e compromissório da Constituição.

Disso tudo, é possível extrair a seguinte assertiva: ou se acaba com a estandardização do direito ou ela acaba com o que resta da ciência jurídica. ${ }^{22}$ Afinal, passados tantos

igualdade e colocou, no centro da gravitação do agir e do pensar a coisa pública, o indivíduo em lugar do grupo social. Com isto, proporcionou condições para promover um tipo de político profissional forjado para privatizar conflitos sociais, jamais para admitir a representação coletiva. Um político liberal; seguramente, não um democrata. As Escolas de Direito, continua Adorno, sempre ensinaram aos bacharéis um modo específico de representar as relações sociais: como relações individualizadas, nascidas do mercado e das quais resultavam tanto o dever político como as obrigações morais. Cf. Adorno, Sérgio. Os aprendizes do poder. O bacharelismo liberal na política brasileira. São Paulo, Paz e Terra, 1988.

${ }^{22}$ É evidente que estou me referindo à cotidianidade das práticas jurídicas, representado pelo universo das centenas de faculdades de direito, os inúmeros cursos de preparação para concursos e a operacionalidade do direito massificada e sufocada pelo excesso de processos e pela desfuncionalidade do sistema processual. Despiciendo registrar a importância da crescente produção teórica (também em qualidade) ocorrida nos últimos anos, mormente no campo do direito constitucional, fruto principalmente da expansão da pós-graduação stricto sensu (há, hoje, 62 programas de mestrado e 17 programas de doutorado em funcionamento). Essa benéfica influência já se faz notar nas decisões judiciais, proporcionando relevantes avanços doutrinários e jurisprudenciais. anos e em pleno paradigma do Estado Democrático de Direito, do giro lingüístico e do neoconstitucionalismo,

a) ainda não se construiu um modelo de ensino que "supere" a leitura de leis e códigos comentados (na maioria das vezes, reproduzindo conceitos lexicográficos e sem nenhuma sofisticação teórica);

b) a doutrina, a cada dia, doutrina menos, estando dominada por produções que buscam, nos repositórios jurisprudenciais, ementas que descrevem, brevissimamente, o conceito do texto enquanto "enunciado lingüístico";

c) uma simples decisão de tribunal vira referência - plenipotenciária - para a atribuição de sentido do texto, perdendose a especificidade da situação concreta que a gerou;

d) em muitos casos, interpretam-se as leis e os códigos com base em julgados anteriores à Constituição, o que faz com que determinados dispositivos, mesmo que sob um novo fundamento de validade, sejam interpretados de acordo com a ordem jurídica anterior;

e) a doutrina especializada em comentários de legislação não tem efetuado uma filtragem hermenêutico-constitucional dos Códigos e leis, com o que casos nítidos de aplicação direta da Constituição acabam soçobrando em face de legislação produzida há mais de cinqüenta anos, como foi o caso da presença (obrigatória) do advogado no interrogatório do acusado, à qual a doutrina e os tribunais resistiram até o advento da lei no ano de 2004; 
f) até mesmo em determinados setores da pós-graduação stricto sensu (mestrado e doutorado) continua-se a fazer descrições de leis e casos (há dissertações e teses tratando de temáticas monográficas, mais apropriadas para cursos de especialização, para dizer o menos) - a maior parte desvinculada das linhas de pesquisa dos cursos, como, v. g., limitação de fim de semana na lei de execução penal, cheque pré-datado, saídas temporárias na lei de execução penal, inquérito policial, recurso de ofício, perda de bagagem em transporte aéreo, sistema postal, análise jurídica do lixo, o papel do oficial de justiça, o papel do árbitro, suspensão condicional da pena em ação penal privada, embargos infringentes, embargos declaratórios, união homossexual (em um Programa de Pós-Graduação que trata de meio-ambiente), embargos de execução, agravo de instrumento, exceção de préexecutividade, infanticídio, além de uma tese que, em pleno Estado Democrático de Direito, arrasa com o poder constituinte e uma outra que propõe a "inversão do ônus da prova penal" em crimes do colarinho branco etc;

g) por outro lado, nem sequer conseguimos elaborar um novo modelo de provas de concursos públicos, continuando com a tradicional múltipla escolha espaço (indispensável) para personagens fictícios como Caio, Tício e Mévio e com questões dissertativas sobre casos jurídicos (no mais das vezes, sem qualquer sentido "prático") ou sobre conceitualizações jurídicas; h) o modelo de decisão judicial continua o mesmo há mais de um século: a fundamentação restringe-se à citação da lei, da súmula ou do verbete, problemática que se agrava com a institucionalização da súmula vinculante. Daí a (correta) exigência Dworkin de uma "responsabilidade política" dos juízes. Os juízes têm a obrigação de justificar suas decisões, porque, com elas afetam, os direitos fundamentais e sociais, além da relevante circunstância de que, no Estado Democrático de Direito, a adequada justificação da decisão constitui-se em um direito fundamental. O sentido da obrigação de fundamentar as decisões previsto no art. 93, IX, da Constituição do Brasil implica, necessariamente, a justificação dessas decisões;

i) um dos indicadores da prevalência das posturas positivistas - e, portanto, da discricionariedade judicial que lhe é inerente - está no escandaloso número de embargos de declaração propostos diariamente no Brasil. Ora, uma decisão bem fundamentada/justificada (nos termos de uma resposta correta-adequadaà-Constituição, a partir da exigência da máxima justificação) não poderia demandar "esclarecimentos" acerca da holding ou do dictum da decisão. Os embargos de declaração - e acrescentese, aqui, o absurdo representado pelos "embargos de pré-questionamento" (sic) - demonstram a irracionalidade positivista do sistema jurídico;

j) registre-se o componente simbólico (lembremos Lacan e Castoriadis) desse problema: somos, provavelmente, o único 
país do mundo que mantém um "recurso" (embargos declaratórios) para compelir um juiz ou tribunal a fundamentar (explicitamente) aquilo que decidiu, muito embora a própria Constituição determine que todas as decisões sejam obrigatoriamente - fundamentadas. Ora, parece óbvio que uma decisão carente de adequada (e necessária) fundamentação não enseja embargos de declaração. ${ }^{23}$ É, sim, nula, írrita, nenhuma;

k) as decisões devem estar justificadas e tal justificação deve ser feita a partir da invocação de razões e oferecendo argumentos de caráter jurídico, como bem assinala David Ordónez Solís. ${ }^{24} \mathrm{O}$ limite mais importante das decisões judiciais reside, precisamente, na necessidade da motivação/justificação do que foi dito. ${ }^{25}$

${ }^{23}$ Para registrar a dimensão do problema: depois de dizer que o pedido de respeito à hierarquia das leis era um "argumento singelo", o juiz do processo n. ${ }^{\circ}$ 023/1.05.0006047-6, do Estado do Rio Grande do Sul, respondendo aos embargos declaratório interpostos por uma das partes, acrescentou: "Todavia, não há que se exigir respeito a lei e praticar injustiça". E não "conheceu" os embargos.

${ }^{24}$ Cf. ORDóneZ SOLIS, David. Derecho y Política. Navarra, Aranzadi, 2004, pp. 98 e segs.

25 A temática relacionada à discricionariedade e (ou) arbitrariedade não parece ter estado na pauta das discussões da doutrina processual-civil em terrae brasilis. Entretanto, alguns autores, como Ovidio Baptista da Silva, mostram-se contundentes contra qualquer possibilidade de decisionismo judicial (Processo e Ideologia: o paradigma racionalista. Rio de Janeiro, Forense, 2004). Em linha similar, Carlos Alberto Alvaro de Oliveira acentua que a solução entre justiça e formalismo concreto - decorrente de o juiz estar diante de lei injusta ou iníquia, "deve encontrar encaminhamento dentro do discurso jurídico, proferido este com a linguagem que lhe é própria. E o discurso jurídico só obriga até onde conduza sua força de persuasão, força vinculante que há de assentar na lei,
O juiz, por exemplo, deve expor as razões que lhe conduziram a eleger uma solução determinada em sua tarefa de dirimir conflitos. A motivação/justificação está vinculada ao direito à efetiva intervenção do juiz, ao direito de os cidadãos obterem uma tutela judicial, sendo que, por esta razão, o Tribunal Europeu de Direitos Humanos considera que a motivação integra-se ao direito fundamental a um processo eqüitativo, de modo que "as decisões judiciais devem indicar de maneira suficiente os motivos em que

nas valorações e princípios dela emanantes, ou nas valorações sociais e culturais dominantes no seio da coletividade, enfim, no direito como totalidade, para que tudo não redunde a final em puro arbítrio" (Do formalismo no processo civil, 2.ed., São Paulo, Saraiva, 2003, p. 216). Em outro texto, Alvaro de Oliveira alerta contra a arbitrariedade judicial ( $\mathrm{O}$ formalismo-valorativo no confronto com o formalismo-excessivo. In: Revista da AJURIS. Ano XXXIII n. 104, dezembro de 2006, pp. 55 e segs). Já Tereza Arruda Wambier faz uma contundente crítica à discricionariedade: "o Poder Judiciário não tem discricionariedade quando interpreta (e aplica ao caso concreto) norma que tenha conceito vago, seja proferindo liminares, seja proletando sentenças. Também não o tem quando se trata de verificar quais fatos ocorreram e como ocorreram, analisando o conjunto probatório. E tampouco na atividade preliminar, relativa à formação deste quadro" (Omissão Judicial e embargos de declaração. São Paulo, Revista dos Tribunais, 2005, pp. 350 e segs.; também, Controle das decisões judiciais por meio de recursos de estrito direito e de ação rescisória. São paulo, Revista dos Tribunais, 2001). Na linha de Ovidio Batista, a tese de Tereza Wambier fundamenta-se - muito acertadamente - na absoluta necessidade de fundamentação/justificação das decisões, aproximando-a da exigência da integridade (direito como prática interpretativa) de Dworkin. A autora dá, assim, importante contribuição ao Processo Civil brasileiro, ainda fortemente influenciado e calcado no paradigma racionalista, preocupação constante nos textos mais recentes de Ovidio Baptista da Silva, mormente em seu Processo e Ideologia. 
se fundam. A extensão deste dever pode variar segundo a natureza da decisão e deve ser analisada à luz das circunstâncias de cada caso particular". ${ }^{26}$

Daí a necessidade de ultrapassar o "modopositivista-de-fundamentar" as decisões (perceptível no cotidiano das práticas dos tribunais, do mais baixo ao mais alto); é necessário justificar - fenômeno que ocorre no plano da aplicação - detalhadamente o que está sendo decidido. Portanto, jamais uma

26 Sentenças de 9.12.1994 - TEDH 1994, 4, Ruiz Torija e Hiro Balani-ES, parágrafos 27 e 29; de 19.02.1998 - TEDH 1998,3, Higgins e outros -Fr, parágrafo 42; e de 21.01.99 - TEDH 1999,1, Garcia Ruiz-ES. No mesmo sentido, ressalte-se a posição do Tribunal Constitucional da Espanha (sentença 20/2003, de 10 de febrero): "Este Tribunal, con carácter general, ha reiterado que el derecho a la tutela judicial efectiva, en su dimensión de necesidad de motivación de las resoluciones, implica que las decisiones judiciales deben exteriorizar los elementos de juicio sobre los que se basan y que su fundamentación jurídica ha de ser una aplicación no irracional, arbitraria o manifestamente errónea de la legalidad (por todas, STC 221/2001, de 31 de octubre, FJ 6); haciéndole especial incidencia en reforzar esa obligación de motivación en los supuestos de resoluciones judiciales en el ámbito penal por la trascendencia de los derechos fundamentales que quedan implicados en ese tipo de procedimientos (por todas, SSTC 209/2002, de 11 de noviembre, FFJJ 3 y 4, o $5 / 2002$, de 14 de enero, FJ 2). El fundamento de dicha exigencia de motivación se encuentra en la necesidad, por una lado, de exteriorizar las reflexiones que han conducido al fallo, como factor de racionalidad en el ejercicio de la potestad jurisdiccional, que paralelamente potencia el valor de la seguridad jurídica, de manera que sea posible lograr el convecimiento de las partes en el proceso respecto de la corrección y justicia de la decisión; y, de otro, en garantizar la posibilidad de control de la resolución por los Tribunales superiores mediante los recursos que procedan, incluido este Tribunal a través del recurso de amparo (por todas STC 139/2000, de 29 de mayo, FJ 4)" [TC (Sala 2a), sentencia 20/2003, de 10 de febrero (amparo parcial por falta de motivación de sentencia condenatoria por delitos de imprudencia temeraria y omisión del deber de socorro]. decisão pode ser do tipo: "Defiro, com base na lei $x$ ou na súmula $y$ ", valendo lembrar que esse problema ficará agravado com a institucionalização das súmulas vinculantes introduzidas pela EC 45/04. Para tanto, basta ver decisão do Supremo Tribunal Federal, entendendo como válida decisão que se restringe à invocação de jurisprudência pacífica corroborada posteriormente em enunciado de súmula. Segundo o STF, nesse caso, não se aplica a exigência contida no art. 93, IX, da Constituição (Ag.Reg. no RE 359.106-1-PR). Veja-se o problema decorrente do entendimento do que é fundamentação/ justificação/motivação de uma decisão: para o Supremo Tribunal Federal, basta a citação do enunciado sumular, que é, assim, alçado à categoria de "conceito abstrato", com caráter de universalidade, "mantendo-se" no sistema à revelia de qualquer situação concreta (reduz-se, pois, a problemática relacionada aos discursos jurídicos aos discursos sobre a validade). No referido acórdão, o Tribunal decidiu que não só a decisão que apenas cita a súmula é legítima, como o recurso deve ser dirigido contra a fundamentação dos precedentes em que se alicerça a súmula. Essa tese desborda daquilo que deve ser entendido como jurisprudência e sua consolidação. Além disso, fica a pergunta: se uma decisão que apenas cita a lei é nula, por qual razão uma que cite apenas uma súmula não o é?

Para além da crise aqui denunciada e procurando permanecer fiel às coisas mesmas, à intersubjetividade, ao mundo prático, à faticidade, à busca da construção de um "comportamento constitucional” já referido anteriormente, torna-se necessário superar as diversas posturas que ainda percebem o direito a partir de hipóteses, categorias, de 
construções imaginárias ou de quaisquer outras herdadas da tradição filosófica de indole metafísica (Villalibre).

\section{4 À GUISA DE CONSIDERAÇÕES FINAIS: UM DECÁLOGO PARA EVITAR MAL-ENTENDIDOS S O B R E O PA PEL D A HERMENÊUTICA (FILOSÓFICA)}

Nesta quadra da história, algumas teses tornaram-se lugar-comum no campo jurídico, a partir da formação de uma espécie de unanimidade teórica em torno de assertivas como a de que vivemos a era $d a$ concretização dos direitos constitucionais, a norma (somente) se realiza no "caso concreto", todo o direito privado está “atravessado” pelo público (publicização do direito privado), além da cotidiana ode aos princípios e à jurisdição constitucional.

Isso deveria ser alvissareiro, não fosse a visível crise que decorre da distância entre, de um lado, os direitos proclamados por esse novo paradigma constitucional e, de outro, as demandas decorrentes de uma sociedade carente de atendimento dos mais básicos direitos fundamentais sociais, assim como, até mesmo, dos próprios direitos de primeira dimensão (basta verificar como são tratados os pobres no plano da justiça criminal).

Do mesmo modo, de um lado, a produção acadêmico-doutrinária apontando para o papel transformador do direito e da jurisdição constitucional, sustentada em potentes teorias que têm na interpretação o locus privilegiado de ação, e, de outro, o "bater de frente" com a cotidianidade do ensino jurídico (estandardizado e refém de uma cultura manualesca) e a operacionalidade stricto sensu do direito, mergulhada em uma crise de efetividade qualitativa e quantitativa, ${ }^{27}$ 27 As constantes reformas processuais vem se
restrigindo a busca de "efetividades quantitativas", com
a institucionalização de mecanismos que "delegam" aos
juízos mocráticos a decisão, além da possibilidade da
"reunião" de um número ilimitado de processos para
serem julgados "em julgamento único". Como exemplo,
vale referir a decisão do Supremo Tribunal Federal do dia
09/02/2007, julgando um conjunto de 4908 processos de
pensão por morte. Por maioria, o Tribunal conheceu e deu
provimento aos REs 416827 e 415454 , interpostos pelo
Instituto Nacional do Seguro Social (INSS). O Plenário
analisou todos os recursos em conjunto. Os ministros relatores (Sepúlveda Pertence, Gilmar Mendes, César Peluzo, Carlos Ayres Britto, Ricardo Lewandowski e Cármen Lúcia) fizeram uma triagem em todos os processos sob sua responsabilidade, que tratavam do tema e se enquadravam na decisão dos recursos julgados no dia anterior. O julgamento em bloco tornou-se possível após a alteração instituída pelo artigo 131 do Regimento Interno do STF. A emenda altera o tempo de sustentação oral, de 15 minutos para as causas normais, para 30 minutos nos casos de recursos idênticos ou causas conjuntas. Esse tempo será compartilhado entre os advogados presentes interessados na causa. No início da sessão, o ministro Marco Aurélio levantou questão de ordem, para que os processos fossem retirados de pauta e cada relator, ante o precedente do plenário, atuassem de forma individual. Ele revelou sua preocupação "quanto à inserção em pauta de 4908 processos". Para ele, o INSS advoga para fazer frente a uma avalanche de processos. E que por vezes pode surgir um descompasso entre os fundamentos da decisão e as razões recursais, bem como a falta de oportunidade de observância do prazo recursal. "Jamais a corte fez inserir em pauta processos a revelarem Recursos Extraordinários para serem apreciados sem sequer o pregão específico do processo, mediante remissão a listas”. O Min. Marco Aurélio afirmou que há situações diversificadas em cada um dos recursos, além de situações anteriores diferentes. Por isso a questão de ordem. Ele disse que o julgamento em massa pode provocar a interposição desenfreada de embargos declaratórios. "É um procedimento inédito, que poderá ter desdobramentos nefastos", finalizou o ministro. A ministra Ellen Gracie asseverou que o ato de pautar esses processos resultou de uma iniciativa da presidência da Corte, e contou com a concordância da maioria dos ministros. "Considero que se alguma questão há, perante esse STF, que mereça o título de questão de massa, homogênea e absolutamente uniforme, é exatamente a questão que ontem decidimos nos dois REs chamados a julgamento". Ela ressaltou que tratar como se 
a ponto de se buscar, dia a dia, para além da súmula vinculante, outros mecanismos que "acelerem" e "desafoguem" a prestação jurisdicional (veja-se, v. g., para além do poder monocrático conferido ao relator nos recursos - art. 557 do CPC -, a nova Lei n. ${ }^{\circ} 12.277 / 06$, que institui o julgamento da ação sem a ouvida da outra parte; registrese a edição, por parte de Turmas Recursais de Juizados Federais, ${ }^{28}$ de enunciados

fossem casos individuais, com peculiaridades extremas, uma questão que é absolutamente homogênea, "seria uma perda de tempo". E concluiu dizendo que a proposta de Marco Aurélio, de julgamentos monocráticos por parte dos relatores de cada processo, atrairia, da mesma forma, o agravo regimental (www.stf.gov.br). Mas essa questão não fica restrita ao judiciário (lembremos, nesse ponto, os poderes conferidos aos relatores nos tribunais através de várias mini-reformas levadas a cabo no Código de Processo Civil). Com efeito - e para demonstrar que essa questão é (também) um problema decorrente da formação de um determinado imaginário jurídico (lembremos aqui as antigas, porém ainda atuais, noções de ideologia) - registro notícia publicada no Informativo da Ordem dos Advogados do Brasil (seção Distrito Federal, ano 27, n. 196, novembro de 2005), dando conta de o secretário-geral, durante exercício da Presidência, "deu especial atenção aos processos disciplinares pendentes. Em 48 horas, ele proferiu despachos justificados e fundamentados determinando o arquivamento de aproximadamente 520 representações, após receber os processos, devidamente instruídos, de vários membros do Tribunal de Ética e Disciplina”.

${ }^{28}$ Por todos, o RE 418.918-6-RJ, que afastou, por inconstitucional, o enunciado n. ${ }^{\circ} 26$, pelo qual "decisão monocrática proferida pelo relator não desafia recurso à Turma Recursal", motivando o seguinte comentário do Min. Marco Aurélio Mello: "Mas, aí, verifica-se que as turmas recursais acabam por criar um sistema que é um terceiro gênero, tendo em conta o texto do Código de Processo Civil: o relator pode acionar o art. 557 e chegar, até mesmo, ao julgamento de fundo, reformando a decisão do juízo especial, mas fazendo-o, contrariando uma sistemática que é da tradição do direito brasileiro, a parte prejudicada não tem acesso ao colegiado; fazendo-o, deixa o art. 557 capenga, no que a Turma Recursal afasta o agravo previsto no parágrafo segundo do art. 557. Foi justamente isso que ocorreu no caso, neste processo". "com força de lei" impeditivos de reexame da matéria).

Assim, se é verdade que o direito assume, definitivamente, nesta quadra da história, um caráter hermenêutico, decorrente de um efetivo crescimento no grau de deslocamento do pólo de tensão entre os poderes do Estado em direção à jurisdição (constitucional), também é verdade que, em plena era da "sociedade aberta de intérpretes", do triunfo do constitucionalismo, da argumentação jurídica e da viragem lingüística, a teoria do direito vem sendo dominada por uma crescente sincretização de cunho a-paradigmático.

Conseqüentemente - para aquilo que interessa aos objetivos destas reflexões expressões como "caso concreto", "hermenêutica", "interpretação", "discurso", "argumentação" e "concretização" vêm sofrendo de forte anemia significativa. Em face desse estado d'arte e na medida em que a problemática acerca da interpretação é uma questão que envolve concorrência de ou entre paradigmas de direito, de précompreensões acerca de como se deve interpretar e aplicar direito, na feliz assertiva de Marcelo Cattoni, ${ }^{29}$ algumas advertências se

${ }^{29}$ Isso significa dizer, por exemplo, que a opção pela teoria do discurso habermasiana torna incompatível a utilização da ponderação de princípios de que fala Alexy. Já a opção pela hermenêutica filosófica implica trabalhar, mais do que com a viragem lingüística, com o giro ontológico (ontologische Wendung), com o que ser e ente (na adaptação que fiz para a hermenêutica jurídica, norma e texto) somente subsistem a partir da diferença ontológica, o que implica igualmente evitar qualquer tipo de dualismo metafísico (palavras e coisas, questão de fato e questão de direito, essência e aparência, para referir apenas estas). Optar pelo paradigma hermenêutico (fenomenologia hermenêutica, de matriz heidegerogadameriana) implica abandonar qualquer possibilidade de uso de métodos, metamétodos ou metacritérios interpretativos ou a ponderação (em etapas ou não). 
impõem desde o paradigma da hermenêutica filosófica, isto é, é preciso ter claro que a "opção" por um paradigma implica uma série de compromissos teóricos, com os quais não se pode transigir. ${ }^{30}$ Assim, a hermenêutica não se pretende "imperialista" ou "invasora" de outras teorias, do mesmo modo que não pretende substituir qualquer outra teoria (epistemológica ou não) ou ter a última palavra.

Nessa linha de raciocínio, chamo a atenção para o seguinte decálogo, no sentido de que:

- primeiro, não se pode confundir hermenêutica com teoria da argumentação jurídica, isto é, hermenêutica (filosófica) não é similar a nenhuma teoria da argumentação (e suas derivações); portanto, não é possível com ela (con)fundir - por mais sofisticadas $e$ importantes que sejam - as teses de Alexy, Atienza e Günther, para falar apenas

Também não se pode confundir hermenêutica filosófica com as teorias ligadas à tópica jurídica, como as de Perelman e Viehweg.

${ }^{30}$ Como referido no decorrer da presente obra, entendo que há uma série de aproximações e pontos comuns entre a teoria interpretativa-integrativa de Dworkin e a hermenêutica filosófica de Gadamer. Seu caráter não epistemológico, a não-cisão entre interpretação e aplicação (caráter unitário do compreender), a incorporação da reflexão moral como elemento necessário da decisão judicial (o aspecto normativo incorpora a reflexão moral, perceptível em Gadamer na relação entre o geral e o particular), o rechaço de ambos à arbitrariedade interpretativa, a incompatibilidade com as teorias da argumentação, por serem procedurais e a superação do esquema sujeitoobjeto, entre outras questões. De modo que, embora as observações se relacionem à hermenêutica filosófica, também podem ser válidas para a teoria interpretativa dworkiana, pelos pontos em comum entre ambas e pelas incompatibilidades com as teorias realistas, analíticas e discursivo-procedurais. destas; ${ }^{31}$ também não é possível sustentar que a ponderação (feita em etapas ou não) seja uma "atividade hermenêutica", uma vez que o círculo hermenêutico aponta exatamente para a superação de qualquer atividade interpretativa ligada ao esquema sujeito-objeto, rejeitando, ipso facto, toda e qualquer possibilidade de subsunções ou deduções;

- segundo, quando se diz que a Constituição e as leis são constituídas de plurivocidades sígnicas (textos “abertos", palavras vagas e ambíguas etc), tal afirmativa não pode dar azo a que se diga que sempre há várias interpretações e, portanto, que

${ }^{31}$ De ressaltar o que parece evidente: a tese habermasiana é bem mais sofisticada que a teoria da argumentação stricto sensu. Portanto, as críticas à teoria argumentação não podem ser estendidas, tabula rasa, à teoria do discurso. As críticas à teoria do discurso assumem outra perspectiva, exaustivamente por mim examinada em Verdade e Consenso, op.cit. Mas, ao dizer que os participantes de uma situação discursiva tematizam uma pretensão de validade que se tornou problemática e verificam, num enfoque hipotético e apoiados apenas em argumentos, se a pretensão do oponente tem fundamento, parece que, para Habermas, a obtenção da resposta estará dependente da obediência da forma da argumentação, podendo soçobrar a conteudística, problemática que assume especial relevância quando se tratar da discussão de direitos fundamentais prestacionais. E, com isso, pode soçobrar a Constituição. Observe-se que a "substituição" da tese do consenso por uma "praxis argumentativa", conforme Habermas em Verdade e Justificação, implica colocar toda a ênfase na argumentação, que "permanece o único meio disponível para se certificar da verdade", porque não há outra maneira de examinar pretensões de verdade tornadas problemáticas. Tal circunstância permite uma aproximação da teoria do discurso habermasiana da teoria da argumentação, pela qual, ao fim e ao cabo, somente é verdadeiro um enunciado se estiver em conformidade com um determinado procedimento, isto é, os procedimentos que regram a argumentação (em Habermas, a resposta estará dependente da obediência da forma da argumentação). 
o direito permite múltiplas respostas, circunstância que, paradoxalmente, apenas denuncia - e aqui chamo à colação as críticas de Dworkin à Hart as posturas positivistas que estão por trás de tais afirmativas; por isso, também são incompatíveis com a hermenêutica as teses que sustentam que o advento dos princípios e das cláusulas gerais possibilitam uma (maior) "abertura" 32

${ }^{32}$ Malgrado tais esforços, entendo que, com o advento do constitucionalismo principiológico, não há mais que falar em "princípios gerais do Direito", pela simples razão de que foram introduzidos no Direito como um "critério positivista de fechamento do sistema", visando a preservar, assim, a "pureza e a integridade" do mundo de regras. Nesse sentido, basta observar algumas questões que, pelo seu valor simbólico, representam o modo pelo qual a instituição "positivismo" assegura a sua validade mesmo em face da emergência de um novo paradigma. É o caso de três dispositivos que funcionam como elementos de resistência no interior do sistema jurídico, como que para demonstrar a prevalência do velho em face do novo. Vejamos: mesmo com a vigência de um novo Código Civil desde 2003, continua em vigor a velha Lei de Introdução ao Código Civil de 1942. Um dos pilares da Lei é o artigo $4^{\circ}$, que, ao lado do artigo 126 do Código de Processo Civil, funcionam como uma espécie de fechamento autopoiético do sistema jurídico. Segundo o artigo $4^{\circ}$, quando a lei for omissa, o juiz decidirá o caso de acordo com a analogia, os costumes e os princípios gerais do direito. Em linha similar, temse o artigo $3^{\circ}$ do Código de Processo Penal, também da década de 40 do século passado, segundo o qual $a$ lei processual penal admitirá interpretação extensiva e aplicação analógica, bem como o suplemento dos princípios gerais do direito. Já o artigo 335 do Código de Processo Civil, fruto do regime militar, acentua que em falta de normas jurídicas particulares, o juiz. aplicará as regras de experiência comum subministradas pela observação do que ordinariamente acontece $e$ ainda as regras da experiência técnica, ressalvado, quanto a esta, o exame pericial. Os dispositivos, a par de sua inequívoca inspiração positivista (permitindo discricionariedades e decisionismos), e sua frontal incompatibilidade com uma leitura hermenêutica do sistema jurídico, superadora do esquema sujeito-objeto (filosofia da consciência), mostram-se tecnicamente inconstitucionais (não recepcionados). Ver, para tanto, Verdade e Consenso, op.cit. (liberdade) interpretiva em favor dos juízes, circunstância que recoloca, no paradigma neoconstitucionalista, a principal característica do positivismo: a discricionariedade;

- terceiro, quando, por exemplo, Gadamer confronta o método, com o seu Verdade e Método, não significa que a hermenêutica seja relativista e permita interpretações discricionárias/arbitrárias; portanto, a hermenêutica é incompatível com discricionariedades e arbitrariedades interpretativas;

- quarto, quando se fala na invasão da filosofia pela linguagem, mais do que a morte do esquema sujeito-objeto, isso quer dizer que não há mais um sujeito que assujeita o objeto (subjetivismos/ axiologismos que ainda vicejam no campo jurídico) e tampouco objetivismos; também por isso não é mais possível falar em subsunções ou deduções e dualismos (cisões) entre regra e princípio, casos simples e casos difíceis;

- quinto, quando se popularizou a máxima de que "interpretar é aplicar" e de que "interpretar é confrontar o texto com a realidade", não significa que texto e realidade sejam coisas que subsistam por si só ou que sejam "apreensíveis" isoladamente, sendo inadequado sustentar, portanto, que interpretar é algo similar a "fazer acoplamentos entre um texto jurídico e os fatos" ou, como numa metáfora que circula nas salas de aula, "entre um parafuso e uma porca" (sic), em que o parafuso seria o texto e a porca, a realidade, sendo a aplicação, ipso facto, o resultado dessa "junção"; 
- sexto, de igual maneira, quando se popularizou a assertiva de que o texto não é igual à norma e de que a norma é o produto da interpretação do texto, nem de longe quer dizer que o texto não vale nada ou que norma e texto sejam "coisas à disposição do intérprete", ou, ainda, que depende do intérprete (solipsista) a "fixação da norma"; em realidade, esquece-se que a "norma" deve ser compreendida como o texto em forma de enunciados, em que o conteúdo veritativo não é nada mais do que a dimensão predicativa, isto é, aquilo que se diz sobre ele;

- sétimo, se texto e norma não são a mesma coisa, tal circunstância não implica a afirmação de que estejam separados (cindidos) ou de que o texto contenha a própria norma (as súmulas e os verbetes "proto-sumulares" são a prova disso), mas, sim, que apenas há uma diferença (ontológica) entre ambos;

- oitavo, é um equívoco pregar que o texto jurídico é apenas "a ponta do iceberg" e que a tarefa do intérprete é a de revelar o que está "submerso", porque pensar assim é dar azo à discricionariedade e ao decisionismo, características do positivismo;

- nono, a fundamentação de decisões (pareceres, acórdãos etc.) a partir de ementas jurisprudenciais sem contexto e verbetes proto-lexicográficos apenas reafirma o caráter positivista da interpretação jurídica, pois esconde a singularidade dos "casos concretos";

- décimo, é preciso ter em mente que a reprodução de ementas e verbetes sem contexto apenas enfraquece a reflexão crítica, fenômeno que pode facilmente ser constatado nas práticas tribunalícias (decisões que tão-somente reproduzem ementários), retroalimentadas pela doutrina ("cultura" dos manuais), que vem assumindo, dia-a-dia, um conceitualismo que a joga de volta ao realismo filosófico.

Se é certo que essa corrida em direção à hermenêutica jurídica (nas suas diversas formas e vertentes), isto é, essa "viravolta concretizadora", propiciou efetivos avanços no campo da efetivação dos direitos (lato sensu), também é certo que algumas posturas fomentaram uma verdadeira "ideologia decisionista", em que a situação concreta desaparece no interior da "conceitualização" (conceitos doutrinários, ementas jurisprudenciais descontextualizadas etc.). Ou seja, é a pretensão universalizante dos conceitos prévios, sempre feita a partir da justificativa de que a lei não pode abarcar todas as hipóteses de aplicação. O paradoxal é que, por exemplo, a institucionalização da súmula com efeito vinculante aponta na direção contrária, isto é, parece que os juristas "descobriram" um modo de "abarcar as múltiplas hipóteses de aplicação de uma lei...".

Na verdade, a alusão ao "caso concreto" transformou-o em álibi teórico, a partir do qual se pode atribuir qualquer sentido ao texto e qualquer decisão pode ser produzida. Nesse rol, podem ser elencadas as diversas posturas positivistas, que, de um modo ou de outro, trabalham com a possibilidade de múltiplas respostas, ou transferindo o problema da indeterminabilidade do direito para os conceitos elaborados previamente pela dogmática jurídica (pautas gerais, 
súmulas, verbetes jurisprudenciais) ou deixando a cargo do sujeito-intérprete a tarefa de "descobrir os valores ocultos do texto". Volta-se, pois, ao velho problema: o positivismo e sua principal característica: a discricionariedade, que leva à arbitrariedade e ao decisionismo.

Em reduzida síntese: parece não haver dúvida de que o positivismo - compreendido lato sensu - não conseguiu aceitar a viragem interpretativa ocorrida na filosofia do direito (invasão da filosofia pela linguagem) e suas conseqüências no plano da doutrina e da jurisprudência. Se isto é verdadeiro - e penso que é - então como é possível continuar a sustentar o positivismo nesta quadra da história? Como resistir ou obstaculizar o constitucionalismo que revolucionou o direito no século XX? Entre tantas perplexidades, parece não restar dúvida de que uma resposta mínima pode e deve ser dada a essas indagações: o constitucionalismo nesta sua versão social, compromissória e dirigente - não pode repetir equívocos positivistas, proporcionando decisionismos ou discricionariedades interpretativas.

Isto é, contra o objetivismo do texto (posturas normativistas-semânticas) e o subjetivismo (posturas axiológicas que desconsideram o texto) do intérprete, cresce o papel da hermenêutica de cariz filosófico, que venho trabalhando sob a denominação de uma Crítica Hermenêutica do Direito, com a denominação inicial de Nova Crítica do Direito. Daí a tarefa fundamental de qualquer teoria jurídica nesta quadra da história: concretizar direitos, resolvendo problemas concretos. Nitidamente, ainda há uma resistência à viragem hermenêuticoontológica, instrumentalizada em uma dogmática jurídica (que continua) refratária a uma reflexão mais aprofundada acerca do papel do direito no século XX. De qualquer modo, é possível afirmar, com base na tradição (autêntica) da teoria do direito, que a viragem lingüístico-hermenêutica tem apontado para a superação da metafísica clássica e da metafísica moderna. E o direito, locus privilegiado do processo hermenêutico - porque os textos necessitam sempre de interpretação, questão que a própria dogmática jurídica reconhece -, não pode caminhar na contramão desse rompimento paradigmático. Tais conclusões, exatamente porque sustentadas no paradigma da hermenêutica filosófica, não são, por isso, definitivas. Como já referido acima, a hermenêutica, por ser crítica, está inexoravelmente condenada à abertura e ao diálogo. E, como alerta Gadamer, não quer ter a última palavra!

\section{REFERÊNCIAS}

ADORNO, Sérgio. Os aprendizes do poder. O bacharelismo liberal na política brasileira. São Paulo: Paz e Terra, 1988.

BEDAQUE, José Roberto dos Santos. Efetividade do Processo e Técnica Processual. São Paulo: Malheiros, 2006.

BOURDIEU, Pierre; PASSERON, Jean Claude. A reprodução: elementos para uma teoria do sistema de ensino. São Paulo: Ed. Francisco Alves, 1975.

COUTINHO, Jacinto Nelson de Miranda. Dogmática crítica e limites lingüísticos da lei. Revista do Instituto de Hermenêutica JurídicaCrítica à dogmática: dos bancos acadêmicos à prática dos tribunais, $n .^{\circ} 3$. Porto Alegre, IHJ, 2005.

FERRAZ JR, Tércio Sampaio. Introdução ao estudo do direito. São Paulo: Atlas, 1987. 
FERRAZ JR, Tércio Sampaio. Função Social da Dogmática Jurídica. São Paulo: Revista dos Tribunais, 1980.

HABERMAS, Jürgem. Verdade e justificação. São Paulo: Loyola, 2004.

OLIVEIRA, Carlos Alberto Alvaro de. Do formalismo no processo civil, 2.ed. São Paulo: Saraiva, 2003.

OLIVEIRA, Carlos Alberto Alvaro de. O formalismo-valorativo no confronto com o formalismo-excessivo. In: Revista da AJURIS. Ano XXXIII n. 104, dezembro de 2006.

ORDÓNEZ SOLIS, David. Derecho y Politica. Navarra: Aranzadi, 2004.

SILVA, Ovídio Araújo Baptista da. Processo e Ideologia: o paradigma racionalista.

Rio de Janeiro: Forense, 2004.

STRECK, Lenio Luiz. Bem jurídico e Constituição: da Proibição de Excesso (Übermassverbot) à Proibição de Proteção Deficiente (Untermannverbot): de como não há blindagem contra normas penais inconstitucionais. In: Boletim da Faculdade de Direito de Coimbra, v.80, ano 2004, pp. 303-345.
STRECK, Lenio Luiz. Hermenêutica Jurídica $E(m)$ Crise, 7. ed. Porto Alegre: Livraria do Advogado, 2007.

STRECK, Lenio Luiz. Verdade e Consenso, 2.ed. Rio de Janeiro: Lumen Juris, 2007.

STRECK, Lenio Luiz. Interpretando a Constituição: Sísifo e a tarefa do hermeneuta. Um manifesto de Laurence Tribe e Michael Dorf em favor da proteção substantiva dos direitos fundamentais. In: Hermenêutica Constitucional. Belo Horizonte: Del Rey, 2007.

TRIBE, Laurence; DORF, Michael. On reading the Constitution. President and Fellows of Harward College, 2005.

WAMBIER, Tereza Arruda. Omissão Judicial e embargos de declaração. São Paulo: Revista dos Tribunais, 2005.

WAMBIER, Tereza Arruda. Controle das decisões judiciais por meio de recursos de estrito direito e de ação rescisória. São Paulo: Revista dos Tribunais, 2001.

WARAT, Luis Alberto. Introdução geral ao direito I. Porto Alegre: Fabris, 1994.

ZIZEK, Slavoj. Eles não sabem o que fazem. O sublime objeto da ideologia. Rio de Janeiro, Zahar, 1992. 